\title{
Nature and Extent of Land Disputes in Nandi County, Kenya
}

\author{
Beatrice Mosiria \\ Crispinous Iteyo \\ Kennedy Onkware \\ School of Disaster Management and Humanitarian Assistance \\ Department of Peace and Conflict Studies \\ Masinde Muliro University of Science and Technology, Kenya
}

\begin{abstract}
Worldwide judicial decision making process helps resolve land disputes and its evolution dates back to when judges began resolving land disputes, Kenya and Nandi County are not an exception. Despite the existing judicial mechanisms for resolution, land disputes continue to exist between communities and individuals. Thus the quest for justice continues for the parties involved in land disputes. The study sought to examine the nature of land disputes in Nandi County. The study adopted the attitudinal model for judicial decision making process since it highlights the judicial process in resolution of disputes. It also adopted the social conflict theory which explains why the society conflicts over limited resources owned by the rich while the poor provide labor and are oppressed to the extent of causing conflict. The study targeted a population of 831. The study sampled 260 respondents including; 215 Counsels and 3 judicial officers, 21 community elders and 21 members of the National Land Commission (NLC). The study adopted simple random, census, purposive, convenient and snowballing sampling methods. Primary data collection methods were Questionnaires, Interviews and FGDs. The collected data was analyzed qualitatively and quantitatively through descriptive and inferential statistics. The analyzed data was presented in frequency distribution, tables and graphs. The results indicate that court officials $111(51 \%)$ handle land disputes on weekly basis, $40 \%$ on monthly basis,4(2\%) few per month, and 2(1\%) rarely. Unclear land rights was supported by 100(218) of the respondents as the major cause of conflicts, 205(94\%) cultural practices, 148(68\%) historical injustices, 183(84\%) inequitable access to land, $116(53 \%)$ population growths, while $78 \%$ (170) blamed boundary issues. The study recommends cooperation from both the national and county government to tackle land disputes and alleviate suffering among residents in Nandi County.
\end{abstract}

Key Words: Counsels, conflict resolution, land disputes

\section{Introduction}

Judicial decision making process and resolution of disputes has been researched since judges began resolving land disputes (Andrew, 2003). Most of the studies have revolved around the judicial process and outcomes of disputes. For instance, the great civil codes of eighteenth century of Europe were designed to provide resolutions for all judicial disputes including land disputes. But they proved inadequate in land dispute resolution. Legal doctrines and methodology alone were inadequate in resolving of all land disputes (Barnett and Adger, 2007). In many land disputes, something else more than the legal doctrine and methodology is important to determine the outcome of land disputes. Factors such as the nature of the dispute, the judicial decision making process in relation to land disputes and the challenges faced in resolving land disputes through the judicial process need to be considered, the same factors are addressed herein.

Scrurrah \& Hirsch (2015) point out that the judicial decision making process has not succeeded fully in resolving land disputes especially in Nandi County. The community members have been suffering for many years as a result of the land related disputes. There have been cases of delayed justice which is seen as lack of justice, corruption and cultural beliefs hindering justice. Thus, the community members in Nandi County have not obtained justice which they desire. In this case, therefore, it was the prime interest of this study to examine how the judicial decision making process influences resolution of land disputes in Nandi County.

Land conflicts are a widespread phenomenon, which can occur at any time and place. They can be caused by greed and need, increases in land value and scarcity nature of land accelerates them (Maina, 2015). Whenever there is a chance to obtain land for free land conflicts are inevitable, it does not matter if the land is someone's private property, state or common land. Most inheritance disputes and conflicts between neighbors and families are oftenly about land. Boone (2012) argues that land disputes have become ubiquitous and Nandi County is not immune to these conflicts. 
The promulgation of a new constitution in 2010 has addressed some of the land disputes but more disputes continue to emerge. Out- of- court settlement mechanisms still require formalization of decisions in court to establish whether due process was followed and to evaluate the evidence presented in each dispute decision (Boone, 2012). Further, the County Government of Nandi (2018) Progressive report on historical land injustices acknowledges that some cases take a considerably long period to settle using the out of court settlement mechanisms, these mechanisms are at times affected by power dynamics, the monetary value of the land under dispute and the complexity of the dispute. These trends have called for and increased the need for judicial mechanisms to resolve land disputes. However, certain challenges continue to emerge in the process of resolving land disputes through judicial mechanisms. It is against this backdrop that the current study was carried out. The objective of this study was to examine the nature of land disputes in Nandi County.

\section{Methodology}

This study adopted a descriptive research design. It was carried out within Nandi County. The study targeted the counsels who had dealt with cases within Nandi County courts. Advocates and prosecutors are all counsels who represented litigants and prosecuted cases respectively. It also targeted the judicial officers who are the officials who presided over these cases and passed judgments on them. In cases where the resolution was reached out of court with the help of community elders, the community elders involved were included in the study and were engaged through focus group discussions, and qualitative data collected. The study also included the representatives from the National Land Commission (NLC) who heard and provided the way forward for the conflicts.

Both primary and secondary methods of data collection were used in the study. Questionnaires were used to collect primary data from counsels and judicial officers. Interviews were also used to collect primary data from the officers of the National Land Commission to determine the causes, nature and outcome of land conflicts resolved and formalized through court process. Focus Group Discussions were used to collect data collected from community elders including those who have been litigants within the given scope. Secondary data was collected by examining the NLC reports on the land conflicts in the areas the study covered.

The Conceptual Framework of this study was based on two theories which are Social Conflict Theory by Karl Max (1818-1883) and the attitudinal model of judicial decision-making by Segal and Spaeth (1993).

\section{Data Presentation and Discussions}

\section{Nature and Extent of Land Disputes in Nandi County}

This paper presents results and discussions on the nature and extent of land disputes in Nandi County. It discusses the incidences of conflict; number of times of the conflicts and duration of the conflicts; areas prone to the conflicts; frequency of the conflicts; causes of the conflicts; socio-economic impacts of the conflicts. It further gives the conclusion and recommendation. The study sought to establish the nature and extent of land disputes in Nandi County, which was the first objective of the study. To achieve this objective, the study obtained data from questionnaires, interviews, FGDs and secondary sources.

\section{Frequency and Extent of Land Disputes in Nandi County}

The study sought to investigate the frequency of land disputes in Nandi County. The respondents were asked to indicate how frequent they deal with land disagreements while in the line of duty. The results are indicated in Table 1.

Table 1 Frequency of Land Disputes in Nandi County

\begin{tabular}{|l|l|l|}
\hline Occurrence Rate & Frequency & Percentage \\
\hline Daily & 13 & $6 \%$ \\
Weekly & 111 & $51 \%$ \\
Monthly & 87 & $40 \%$ \\
After a few months & 4 & $2 \%$ \\
Rarely & 2 & $1 \%$ \\
\hline
\end{tabular}

\section{Source: Field Data, 2019}

According to Table 1 the majority of the counsels and court officials 111(51\%) indicated that they handle land disputes on weekly basis. 
The results reveal that there are frequent disputes in Nandi County that require the assistance of the counsels and judicial officers. On the same note, a moderate representation of the respondents representing 87 (40\%) also revealed that they handle land disputes on monthly basis. This is a large number that shows the high occurrence of land related disagreements in the study area. Only a small percentage of $4(2 \%)$ handles conflicts after a few months, and a very small percentage of $2(1 \%)$ indicated that the disputes occur rarely.

During the interviews with members of the National Land Commission, the study found out that there have been frequent land disputes in the region. The respondents indicated that the conflicts have been recurring from time to time. In fact, even the families that have their cases resolved have the conflicts recurring after sometime because the family members are never satisfied. There are continuous conflicts because of recurring causes, some of which are practically impossible to resolve. For instance, the NLC members interviewed indicated that limited land has been one of the major causes of disputes in the area and also unclear policies have increased the disputes. Campbell et al., (2000) observes that ongoing land conflicts in Kenya are due to scarcity of land and other related resources and unclear land policies have increased the frequency and reduced productivity levels. Since it is not possible to extend land, which is a source of conflict and contestation (Vijoen, 2006) the respondents were saddened by the fact that the conflicts might keep recurring until the members of this community find something else to do for economic sustenance.

In agreement with the findings from NLC members, the elders agreed during the FGDs that they have been handling land disputes every day. Members of the community starting with the smallest unit in the community which is the family have frequent disagreements because of land related issues. The elders confirmed that they resolve land disputes every day, and sometimes they have more than two cases to handle per day. The extent of the land disputes is manifested clearly in the words of the elders who sadly indicate that the situation is worsening. One elder pointed out that:

It is sad, unfortunate and disturbing to witness the continuous conflicts, disagreements and even violence that result from land issues. Our people are losing it. Previously, we could handle land disputes after several months. Nowadays it is a daily event. I cannot remember any single week that passed without me being involved in a baraza discussing land issues. I do not know what will happen to our grandchildren, if things are like this today.

A similar opinion was aired by other Kaburwa elder who indicated that:

Unfortunately, there is a lot of secrecy when land issues are concerned. Our people have a culture of preserving their secrets. It becomes hard to resolve the disputes because if you try to dig deep into the root causes of the conflicts, they reply with Mongen (I do not know). In this case, the conflicts keep on recurring. Even if the conflict could be resolved using the available strategies, the culture of secrecy hinders any resolution. As a result, the elders keep on trying to solve the same problem many times without a solution. It is sad because the same family keeps on fighting from one generation to the other without revealing the root cause so that the elders or the court can get a solution.

The results of this study are consistent with a study conducted by Shanguhyia and Koster (2014) who concluded that conflicts in Rift Valley Region keep on recurring. In their study, Shanguhyia and Koster (2014) found out that Nandi County is one of the counties that has high numbers of land disputes in Rift Valley. The land is continuously becoming scarce. The high and increasing population does not bring a promise of future stability. The youths who are completing school with no job opportunities demand for more land from the parents who are already squeezed. As a result, the conflicts keep on increasing. The current study confirmed these results with NLC members, village elders, Counsels and judicial officials confirming that the disputes are increasing every year.

\section{Causes of Land Disputes in Nandi County}

The study sought to establish the causes of land dispute in Nandi County. The respondents were asked to indicate the major cause of land-related disagreements. The results are indicated in Table 2.

Table 2 Causes of Land Disputes in Nandi County

\begin{tabular}{|l|l|l|l|l|}
\hline Cause of conflict & Agree & Disagree & Not Sure & Total No. \\
\hline Unclear Land Rights & $100 \%(218)$ & $0 \%(0)$ & $0 \%(0)$ & $100 \%(218)$ \\
\hline Boundaries & $78 \%(170)$ & $22 \%(48)$ & $0 \%(0)$ & $100 \%(218)$ \\
\hline Lack of Political Will & $46 \%(100)$ & $47 \%(103)$ & $7 \%(15)$ & $100 \%(218)$ \\
\hline Inequitable Access to Land & $84 \%(183)$ & $10 \%(22)$ & $6 \%(13)$ & $100 \%(218)$ \\
\hline Historical Injustices & $68 \%(148)$ & $19 \%(42)$ & $13 \%(28)$ & $100 \%(218)$ \\
\hline Population Growth & $53 \%(116)$ & $33 \%(72)$ & $14 \%(30)$ & $100 \%(218)$ \\
\hline Cultural Practices & $94 \%(205)$ & $4 \%(9)$ & $2 \%(4)$ & $100 \%(218)$ \\
\hline
\end{tabular}

Source: Field Data, 2019. 


\section{Unclear Land Rights}

Unclear land rights appeared to be the main cause of land disputes in the study area. According to the results in Table 2, all the counsels and judicial officers agreed that unclear land rights are a major cause of land disputes in the study area. These respondents have dealt with land disputes in the region for some time and they cumulatively agreed that there is a problem with land ownership in Nandi.

The findings from the questionnaires were confirmed by the National Land Commission members who were interviewed. During the interviews, NLC officers pointed out that most of the land in Nandi County do not have title deeds. This is because of the inheritance issues that have disturbed the community since the colonial period. The people who are currently in the land are descendants of the original owners. Unfortunately, there was no legal transfer of land ownership from the initial owner to the current one. As a result, the descendants of the original owner keep on disagreeing on how the land should be divided.

Similarly, the community elders echoed similar results. They argued that there are a lot of inheritance issues in the county. This is mostly attributed to the cultural practices of the Nandi community. A man owns the land privately, the wives and children do not have a say as far as the land is concerned. As a result, the man makes decisions concerning land without consulting any other member of the family. During the FGDs, the village elders reported that even crucial decisions such as selling of the piece of land are made solely by the man. The woman and children do not even know who has bought the land. The family just sees an "intruder" in their piece of land, and they cannot question. One elder stated that:

In this community, the mzee owns the land alone. Children and the wife/wives are classified as children. They have no rights to question the man. He does what he wants with his piece of land, and they must submit to his final decision. The woman has no say, and she respects that because it has been like that since time in memorial.

Another elder had this to say:

The woman belongs to me, she is my property. Thus, she has no right to ask me questions on how I use the other part of my properties. Furthermore, I bought her with enough cows she belongs to me, just like the children and the land.

The results of the study also revealed that there are a lot of inheritance issues because most men die without dividing the land among the children. During the FGDs, the elders pointed out that most men reserve land issues. As a result, they want to own the land alone even when they are too old. After their death, the children are left to fight for their share. According to the Kalenjin culture, the eldest son inherits his father. As a result, the eldest son may decide to own the land his father left and refuse to share with the other siblings. Such cases bring a lot of dispute in the region.

The study is in line with the observation in (Bogale et al.2006; Rugege et al., 2007) where it was stated that majority of population in Africa have limited access to land ownership resulting in high levels of vulnerability and resultant conflicts due to lack of security that land can offer especially to the vulnerable groups like women and children.

During the interviews with NLC officers, the issue of inheritance was also reported to be common in the region. The commissioners noted that inheritance related issues are rampant in Nandi County. Daughters are disinherited. They are not allowed to inherit anything their father had as they should get married and acquire land from their husbands. In case the daughters do not get married, or for some reason the marriage fails to work, the daughters have nowhere to go. It is unconstitutional to deny the daughters inheritance as all children are equal before the law.

According to the Law of Succession, Cap 160 Laws of Kenya, Section 29 of the Act defines what a dependant is and it includes wife or wives or former wives, and the children of the deceased whether or not maintained by the deceased immediately prior to his death, also includes such of the deceased's parents, step parents, grand-parents, grandchildren, step-children, children whom the deceased had taken into his family as his own, brothers and sisters, half-brothers and half-sisters, as were being maintained by the deceased immediately prior to his death. All these people are entitled to inherit what has been left behind by the deceased it does not matter whether they are boys or girls and courts uphold the rights of all dependants in a succession matter, this buttresses the provisions of the Constitution of Kenya. The constitution as pointed earlier recognizes equality of men and women. A competent court will have to distribute the property to ensure every dependant gets a share, the notion of discriminating between boys and girls in inheritance issues is abhorred by our laws, hence it is illegal and unlawful and the courts are there to defend these rights. 
In most cases, when the man in the family dies, his brothers want to take over his land. It was reported by NLC members and Kaburwa elders that lack of proper inheritance plan leaves the family susceptible to the brother(s) of the deceased. The brothers want to take over the land and evict the family of the deceased. They argue that if the woman wants to continue owning the land, she must agree to be inherited as well. One NLC commissioner pointed out that:

The culture in this region has oppressed the woman for many years. Imagine after the death of a husband, the woman and her children can be evicted any time and have their land taken over by the brothers. In most cases, the woman is only allowed to remain in the land if she is taken over by one of the brothers. If she refuses, she is told to forget the piece of land.

The results of this study are in agreement with Medard (2010) who pointed out that inheritance issues have been causing endless conflicts in Africa. Despite the fact that African countries have enjoyed freedom for several decades now, they have not seen the importance of setting their things right before death (Medard, 2010). Those who do so eliminate their daughters in the inheritance plan, advancing the culture of woman oppression contrary to the law.

\section{Boundaries}

According to Table 2, 170(78\%) of the Counsels and Court officials agree that boundaries have been a major cause of land disputes in Nandi County. Having dealt with land issues for some years, they believe that there have been boundary issues among family members, neighbors and even the neighboring counties. Only 48(22\%) of the respondents viewed that boundaries have not been a big issue.

During the FGDs, the elders confirmed that land dispute is a major challenge that undermines cohesion among the members of a community or communities. Border disputes are among the major causes of land disputes. Since time immemorial, the communities living in Nandi County have been conflicting because of boundaries. During an interaction with the community elders, it appeared that clashes brought about by border disputes were rampant. One elder declared that:

We have been engaging in border clashes with our neighbors for ages and it has come to a level where the government has to intervene and resolve the matter ultimately. Undefined territorial borders have been the major cause of these incidences. Ethnicity battles have also contributed to the border clashes between members of the Nandi community and those of the Luo community.

Interviews with the members of the National Land Commission yielded same findings. The NLC members' claims seemed to conspire with some of the claims from the community elders; hence the issue of border dispute seemed to result from a common phenomenon. It is hereby clear that measures put in place to help solve the matter were always met by challenges that hindered their proper functioning. In response to this issue, one NLC member stated that:

Boundary disputes have been on the rise in Nandi County. Events of inter-community battles have come as a result of inconsistent borderlines that are always altered and seem contradicting to members of both communities. Some members coming from both communities are always revolting against any alterations and developments made to help settle the issue of borders.

The study did not stop at that as interviews were conducted on some of the judicial officers to get a sneak peek at how the justice system was handling the matter of border dispute in the county. The matter was clearly a bother and it led to a series of inconveniences even as the justice system tried to resolve it. According to their response, cases that remained unresolved became even sourer as time went by. Some of them had something common to state about the system:

The justice system has been trying to come through in the best way possible for all those affected by border disputes in Nandi County. Some cases involving the adjustment and introduction of borders have remained unresolved in court. Due to this standstill situation, ethnic tensions have been worsening between the communities involved.

However, some elders had a contradicting opinion. A section of elders during FGDS agreed with the $22 \%$ of the counsels and court officers who felt that the Nandi community has since time in memorial respected boundaries. Every member of the community knows where to graze, farm and where not to touch. They argued that it is the foreigners who have come and are ignorant on the importance of boundaries. Thus, the conflicts arising as a result of boundaries are caused by new settlers in the county. The elders stated that even their neighbors such as Luhyas who have been their long-term neighbors understand and respect boundaries.

This opinion appears to be a way of defending their community. It also shows the bitterness the community has because of the non-locals who have come to settle in the Nandi County. 
There have been ongoing boundary conflicts between Kisumu and Nandi counties. This is backed by a report issued by the Daily Nation newspaper on the $19^{\text {th }}$ of June 2018.

According to this report, members of the Nandi County Council led by its former chairman, Charles Tanui stated that it all started after there was a petition by Jaramogi Odinga to the founding President, Jomo Kenyatta. The then Vice President of Kenya put in a request for the President to assent to the idea of temporarily allocating part of the Nandi Hills to some of the members of the Luo community to salvage them from the wrath of the floods. The President offered his consent but even after the fall of the Vice President, the Luos prolonged their stay until the death of the President in 1978 (Daily Nation, $19^{\text {th }}$ June, 2018). Following this arrangement, there have been occasional incidences of clashes between descendants of these two communities, each claiming ownership of the land.

Kagwanji (2009:4) observes that the question of the use and ownership of land and access to the related resources is at the center of fostering conflicts between communities in Africa, this is due to various dimensions affecting the communities politically, ethnically, and religion wise. This observation agrees with the findings of this study above.

\section{Lack of Political Will}

Table 2 indicates that $46 \%$ (100) of the respondents agreed that lack of political will has been causing land disputes in the study area, while 47\%(103) felt that political will has nothing to do with land disputes. The remaining $7 \%$ (15) was not sure of the relationship between political will and land disputes. The respondents have differing opinions as they have different stands as to the power and influence of political leaders. Those who attribute political will to disputes feel that politicians are the leaders who should handle issues that affect their subjects. They can even use their power to influence the behavior of the people so that they can change their attitude and shun land conflicts. Further, they can use the resources available to initiate public awareness on the impact of continued conflict. Unfortunately, the politicians do not do that. Results from the open ended questionnaires from the counsels, it was stated thus:

The politicians should have no claim over the land. None of them has made any presentation of proof of ownership and they are known for exactly what they are doing right now. There have been beliefs that a few dynasties should be allowed to acquire a better part of the land regardless of the means, both private and public land, yet we never hear of any prosecutions made against them.

The study went on ahead and interviewed members of the National Land Commission. They also felt that politicians have been contributing towards the land disputes in the area. Instead of bringing solutions, the political leaders fuel the disagreements and promise to support their followers with weapons if things worsened, and they incite the people to go on attack or invade lands in dispute including claims that the lands belong to their community. The political leaders are highly influential and their words are obeyed by the civilians, irrespective of their destructive nature. During the interviews, one of the NLC members stated that:

We as the National Land Commission have received complaints about politicians taking advantage of their former or current positions in government to acquire land that is not legally entitled to them. Indictments have been made and the cases are with the Criminal Investigation Department where investigations are currently underway to determine the credibility of those claims.

During FGDs with the village elders, the study asked some of the Kaburwa village elders to give their take on the matter. The discussions were conducted all over the county and it was clear that the village elders, being leaders themselves, were disappointed in their political counterparts. They claim that the politicians are misusing the locals. They use their power to influence the people negatively. The village elders in the FGDs pointed out that:

It is now clear to us as a community that we obviously have made some wrong choices when it comes to leaders. Our leaders are now playing dirty politics on the citizens. They should be putting forward ways to help solve this problem of land disputes, but instead, they are the ones causing this stalemate. We have lived on this land since our forefathers' times and it makes us least comfortable to bear with the idea that someone could claim the land we inherited. The government should chip in and give us a voice.

Politics have also played a major part in the land disputes experienced in Nandi County. On the $4^{\text {th }}$ of September 2018, Tom Matoke, a reporter with the Business Daily paper, stated that some distinguished politicians who served in the Moi regime were engaged in conflict with squatters who had settled in the Agricultural Development Corporation (ADC) Land in Nandi.

This caught the attention of the ADC management as well as the county government of Nandi who advised the squatters to pay no attention to the veterans' stand of vacating their current premises, which the squatters termed as a 
plot to rob them of the land that formerly belonged to their grandparents (Business Daily, $4^{\text {th }}$ September, 2018). This led to a heated row among the involved parties on who is the rightful holder of the property.

The findings of the study agree with a study conducted by Shanguhyia and Koster (2014) that concluded that politicians exploit the confidence that the citizens have in them. There have been cases where politicians have been known to incite and even finance bandits to engage in land disputes with other communities (Shanguhyia \& Kosters, 2014). Some of those in top positions are also known to illegally allocate land to those who are close to them especially relatives and allies in government. Mismanagement of public land by politicians is also a major cause of land disputes. Public utility facilities such as market places, which are under the mandate of politicians, should be built on the intended locations. Some try to influence the placement of such infrastructure which could result to a feeling of discrimination against one community causing its members to respond negatively.

\section{Historical Injustices}

The results in Table 2 shows that $68 \%$ (148) of the counsels and judicial officers believe that historical injustices cause conflict, 19\%(42) disagree, and 13\%(28) did not know. The findings confirm that majority of the respondents think that there are a lot of historical injustices in the Rift Valley region that make the respondents to remain bitter. The colonial government and the national governments have not helped the residents to handle the injustices. Justice has been delayed for so long. Consequently, the people are uncomfortable as they feel that no one cares for them.

According to the results from the questionnaires administered to the counsels and court officials involved in solving the land dispute cases, historical injustices are a major cause of disputes in the study area. Unfortunately, the counsels pointed out that it is hard to follow up the cases, considering the fact that these injustices started over five decades ago. It requires a lot of political will, cooperation from the public as well as finances to do so. In this case, the injustices keep on haunting the community and increasing tensions whenever residents remember them. In an open ended questionnaire, one counsel wrote that:

Some of these historical injustice cases are dated way back, and conducting a follow up on them requires a lot of commitment. There have been prolonged standoffs between members of the communities involved, some claiming to be the natives even during the pre-colonial period while some claim to have been born after their parents were brought in by the white settlers, making the land their only home.

During the FGDs, the village elders argued that historical injustices practiced during the colonial era would then lead to major disagreements about land ownership in Nandi even during the post-colonial era. This is in agreement with Songer and Link (2010) who argue that during colonization, the Imperial government had laid out a system of land ownership that allocated the most resourceful parts, commonly known as the White Highlands, to the colonialists while the native Africans were only allowed to own the less productive parts. The Nandi resistance, which was a rebellious movement forged against the colonial government, was led by Koitalel Arap Samoei to oppose the settlement of the British in their land (Songer\& Link, 2010).

During the FGDs, the elders continued to narrate that after the decolonization of the lands previously held by the British, the native communities have since engaged in conflict, each of them claiming to be the authentic owner of the property. This has led to occasional clashes between members of the Nandi community and other communities like the Kikuyu who have occupied some parts of the Rift Valley since the colonial period. According to the elders, every once in a while when the political temperatures in the region heighten, it brings about the subject of intruders and the Kikuyus are always seen as the offenders by their Kalenjin counterparts. The study was conducted by interviewing members of the community. On one occasion, some colonial war veterans who are also community elders were asked to give their take on the subject. One village elder explained in Kiswahili that:

Naamini kuwa hii ni ardhi ya mababu zetu. Wakoloni walikuja na wakaleta wageni ambao sasa wanadai hii ni ardhi yao. Waliporudi kwao, walituacha sisi wenyeji tukizozana mpaka sasa.Hivi vita vya kikabila vimesababisha utengano na hata umwagikaji wa damu.(I believe that this is our ancestral land. The colonialists came and brought other people with them who now claim it to be their own. They sure left us in a standoff state which persists up to after they are long gone. These ethnic tensions have brought about dispute and to a far extent, bloodshed).

The study found out that the community members were uncomfortable with other communities who have acquired land in their native and succeeded in business while their own members are still suffering. The elders could not hide their disappointment on this issue. 
They felt that their descendants will not have enough land, and that's why there have been continuous disputes. Despite the fact that land is continuously becoming scarce, the foreigners who acquired the land illegally are still enjoying the land whereas the "rightful" owners are suffering. The study findings are consistent with some media findings by Kahura 2019. In a report by Dauti Kahura, he came across a native inhabitant of the Rift Valley region who seemed relentless about the issue of land ownership by members of the Kikuyu community.

The native referred to the Kikuyu as "tenants on our land" and went ahead to state that at one point, the "intruders" will have to vacate the land regardless of whether they acquired it legally or not (Kahura, 2019).

The researcher paid a visit to the National Land Commission to get a report on how the commission was handling the issue of land dispute in Nandi County as a result of historical injustices. Earlier on, there had been claims that the commission was reluctant in ensuring the compensation of those who lost their land to the colonialists. To avoid any contradictions, the commission was given a chance to tell its side of the narrative. The NLC officers revealed that during the colonial era, the system of land ownership was laid out in such a way that it was quite unfavorable for the Africans. This is in agreement with Branch (2009) argument that the white settlers were allocated large tracts of land while the native owners of the land were left landless. The system also privatized the ownership of land as opposed to the pre-colonial times where land was owned communally.

According to Branch (2009), the historical injustices propagated by the colonial government on the indigenous land owners have been a serious issue since independence although the government has intervened to ensure that justice is served. Up to date, some communities still engage in endless battles, some amongst themselves and some with the government, in pursuit of their cultural land. The system of land ownership as a result of the colonial era has made matters more intense and has hence escalated the level at which land disputes have been occurring.

\section{Population Growth}

As shown in Table 2, 53\% (116) of the respondents who filled the questionnaires agree that population growth has been a major cause of land disputes in the study area. On the other hand, a good number of counsels and court officials adding up to $33 \%$ (72) disagree with that statement while 14\%(30) did not know. Population has been growing rapidly in most parts of the country. As a result, resources have become scarce, and people are left with few means of survival. Consequently, they have to fight for the limited resources, land being the major one that people use to survive.

The findings from the study indicated that population growth has added pain to the already hurt community in the study area. According to Elkins (2005), land is also an essential subject in the settlement of a population. If there is not enough land to hold a rapidly growing population, then the matter of land dispute is likely to come up in the scramble of this vital resource. New settlements are always being built and this shows just how much available land is favorable for the accumulation of the new settlers (Elkins, 2005). During FGDs with the village elders, the study found out that there is a high population growth rate that is increasing the demand for the limited resources. Community elders who have been inhabitants of the study area for long enough to have witnessed the gradual increase in population in the county and its contribution to land dispute. One of the elder's revelations in Swahili was as follows:

Hivi karibuni tumekuwa na shida ya upungufu wa ardhi ya kilimo, ufugaji na makao. Yote haya yanatokana na kuongezeka kwa watu hapa katika county ya Nandi.Tumekuwa tukipokea wageni ambao wanahamia hapa kwa sababu za kikazi na kimasomo. Hii imesababisha vita mara kwa mara baina ya wageni hawa na wenyeji haswa katika misimu ya kiangazi ambapo kuna upungufu wa ardhi ya ufugaji. (Recently, we have experienced an insufficiency in land for agriculture, livestock farming, and settlement. All this has come as a result of population growth here in Nandi County. We have been receiving new settlers who come to live here for professional and educational purposes. This has caused occasional clashes between the new comers and the natives especially during the dry spell when there is a shortage in land favorable enough for livestock keeping).

The National Land Commission had also been trying to handle the matter of rapid population growth as a result of demographic shifts among other causes. Being the oversight body that oversees the even distribution of land amongst the population, the commission has had to face the issue of land dispute caused by population growth in Nandi County. According to a statistic forum held by the county government of Nandi on its Demographic Dividend Potential, the population of the county was at 830,763 in 2014 and 884,749 in 2017. Projected at the same scale of growth over the past years, the figure is estimated at 1.2 and 1.5 million people by the years 2030 and 2050 respectively (Nandi County, 2018). This increase in population is expected to be accommodated on the same limited land over the years. 
The researcher paid a visit to the National Land Commission to get its view on the issue of population growth. Some of the members opined that the issue of land disputes due to population growth has been among a thorn in the flesh since a tremendous increase in settlement has been witnessed within the county borders. Farming land has also been affected as a result, and this has led to the residents moving into other restricted areas such as forest reserves to satisfy their needs of agricultural production and new habitat for the new settlers. The Judiciary was also sucked into the matter since it had received a great deal of legal issues pertaining to land ownership as a result of population density.

According to a petition submitted to the Senate by Joel Kenduiywa, a native of the Ngerek community sub -group, the government through the Kenya Forest Service intended to forcefully evict the community from the South Nandi Forest in Nandi County for purposes of conservation and protection. It was later revealed that there had been other unlawful occupants in the forest and they were the ones behind the intended eviction of the 244 Ngerek families. After a court battle, the court ruled out that the Ngerek community is the legal occupant of the land (Kenduiywa, 2018). Apparently, population growth in the county was the cause of the row since the Ngerek community claimed to have owned the land even before independence.

The study sought clarification from some of the counsels and judicial officers involved in the legal battles and some of them opined that:

Eviction cases have been on the rise especially over the last two decades. This has come as a result of rapid population growth in the county and communities find it necessary to engage in land ownership battles because as time goes by, it becomes essential that each community has to keep up with its demand for more land. Unfortunately, this growth is experienced all over the county hence involving all the communities in the war.

However, some respondents believed that population growth is not a major cause of conflicts. In agreement with $33 \%$ (72) are the counsels and court officers who do not think that population growth causes disputes, some of the NLC officers also disagreed. They argued that there has been population growth in all parts of the country, and people hardly have the conflicts like those that are witnessed in the Rift Valley Region and especially Nandi County. They felt that there are other causes of conflict that make the study population to keep fighting. In their argument, if population growth was a major factor, there would be such disputes in all parts of the world since population has been growing rapidly in most parts of the world and the country. In this case therefore, they disregarded population growth and argued that focus should be given on other factors that can be resolved. One NLC member had this to say:

In my view, population growth has nothing to do with conflicts. These people just fight because they want to do so. Furthermore, we have population growth in the Western region and we hardly have the magnitude of land disputes found in this region. Since there is nothing we can do to reduce the current population, we should focus on other factors that we can handle such as historical injustices.

Hughes (2006) agrees with the results of this study and adds that there could be more incidences of land dispute as growth in population is not likely to cease at any time. As time goes by, the available resources are more likely to get depleted by their utilizers (Hughes, 2006). Lack of proper strategies to rejuvenate the exhausted land for production as well as the negligence of the available land has also contributed to the insufficiency of well-conditioned land since it is the most used up part by the ever-growing population for production.

In agreements with the results of this study, Kabira (2015) points out that rapid growth in population brings about scarcity of resources because the level of supply does not match the level of demand in such cases. Land being one of those resources that are likely to become limited under the circumstance. Most people depend on the land for settlement, agriculture as well as business purposes. The scarcity of land could lead to poverty, poor settlement, limited land for food production and dispute over its ownership. A report revised by Prof. Kabira (2015), revealed that majority of food production in Nandi county was done through crop farming at the rate of $67.5 \%$ with other ways of earning a living such as casual laboring coming at $17 \%$, trade and businesses added up to $8.5 \%$ with regular month salary earnings at the rate of $4.7 \%$. Aid from relatives and livestock sales were at $1.4 \%$ and $0.9 \%$ respectively (Kabira, 2015). From the above statistics, it is clear that a better part of the county's population depends on agricultural land for their food security. If the population growth exceeds the scale of agricultural production, it could lead to food shortage which could end up in conflict.

\section{Cultural Practices and beliefs}

The findings as shown in Table 2 reveal that cultural practices were a major cause of land disputes. The results indicate that $94 \%(205)$ of the counsels and court officials agree that cultural practices and beliefs contribute greatly to land disputes in Nandi County, while only 4\%(9) had a different opinion. 
Majority of the counsels had worked in Nandi County for more than 3 years, and have witnessed a lot of cultural practices and beliefs that contradict the law and some end up causing disagreements among the residents of the study area. A small percentage of 2\%(4) did not know about the cultural practices and beliefs that cause land disputes.

The results presented in this study show that there is a conflict between the law and some cultural practices in Nandi County. The community elders reveled that there are instances where the Nandi Woman is allowed to marry another woman. During the FGDs, the village elders narrated that whenever a couple fails to bear children, the culture and norms of the Nandi allows the woman to "marry" another woman who bears children on her behalf.

The woman pays the dowry and the other woman who is now the "wife" comes to stay with her at her husband's home. In most cases, the two women stay at the same homestead. The woman who has been married submits to the woman who married, and is not allowed to sleep with the husband of the woman who married her. The clan gets a man who will bear children with the newly married wife. The children will belong to the barren couple and will take the family name. Unfortunately, when the woman who is the "husband" in this case dies, there are a lot of conflicts within the family. The woman is mostly denied a chance to inherit land that belongs to the late woman who was her "husband". Since the "husband" has no land rights and depended on her real husband's land, it is unclear which land the supposedly widowed woman should inherit. In such instances, the woman is left with nowhere to go since even her parents cannot accept her as dowry was paid and she no longer belongs to her matrimonial home. If the matter goes to court, the entire arrangement is not recognized by the law.

According to the Constitution, people from the same gender are not allowed to marry each other. Chapter 1 of the Constitution of Kenya, Article 2 (4) provides that any law, including customary law, that is inconsistent with the constitution, is void to the extent of the inconsistency, and any act or omission in contravention of this constitution is invalid. Article 45(2) of the constitution provides that every adult has the right to marry a person of the opposite sex, based on the free consent of the parties. Further (3)(b) provides that a marriage under any system and family law under any tradition, or adhered to by persons professing a particular religion is recognized by the constitution to the extent that any such marriages or systems of law are consistent with this constitution. It is clear from the foregoing that the woman to woman marriage practiced by the Nandi according to their culture and belief cannot be recognized by the constitution since it offends provisions of Article 45 (2) on family, which provides for marriage of adults of opposite sex. This follows that the courts cannot enforce the rights of the parties in a woman to woman marriage since the same is not recognized by law to be a marriage as contemplated under the constitution of Kenya, 2010.

The study found out that there are other cultural practices such as pastoralism that contribute to land disputes in Nandi County. The counsels and judicial officers engaged during this study argued that differences in cultural preferences among communities have led to frequent land disputes since all the communities hold on to their property, either land or livestock, with some sentimental value. In agreement with the finding from this study, Kagwanja (2003) points out that the pastoralist communities have to ensure the survival of their livestock as this guarantees them their own survival too. On the other hand, communities that engage in farming activities have to ensure that their lands are productive throughout the seasons to ascertain their own food security. This causes strife between the pastoralists themselves and also between the pastoralists and the farmers.

The cultural practice of cattle rustling and revenge has also contributed greatly towards the conflicts. The village elders during FGDs argued that the Nandi warriors are not allowed by their cultural belief to accept defeat. They should fight back and get their stolen animals back. They should occasionally go to the neighboring communities and get animals so that their herds can increase. Unfortunately, such practices are illegal. The constitution of Kenya outlaws deprivation of one's property in any way. Article 40 of the constitution states that: (1) any person can acquire and own property of and description; (2) (a) no government agency or person shall arbitrarily deprive a person of property of any description or of any interest in or right over any property of any description or (b) to limit, in any way restrict the enjoyment of any right under this Article on the basis of any grounds as specified in the constitution. Cattle rustling is clearly deprivation of another person's enjoyment of their property and which under Cap 63 Penal Code is an offence called Stock theft contrary to section 278 of Penal Code and a person found guilty is liable to imprisonment for a period not exceeding 14 years for this offence.

During the interactions with the elders, it was revealed that climate changes have also been a contributing factor to the adverse weather conditions that lead to herders-farmers clashes. Retaliation attacks were also a cause of the disputes since every time a community moved into the territory of another community, they were met with hostility and driven away whereby they organized wreak bandits for payback. This was among the elements that made it difficult to solve the quarrel permanently because every community wants to dominate its rival for territorial purposes. An elder who also identified himself as a herdsman pointed out in Kiswahili that: 
Tumekuwa tukihangaika na mifugo yetu kwa muda mrefu tukitafuta maji na chakula. Kiangazi inasababisha sisi tuhame na tukienda kutafuta malisho pande nyingine, tunafurushwa na wenyeji wa sehemu hizo ilhali sisi tunaangamia na mifugo wetu. Wale nao (Maasai) wakija kwetu, mtindo unakuwa ni ule ule wa vita na maangamizi. (We have been struggling for a long time trying to find pasture and water for our livestock.

The drought has forced us to move but every time we find grazing land in other places, we are met with hostility from the natives of those regions yet we are at the brink of death with our animals. When the Maasai come to our land for grazing, it becomes a trend of war and destruction.

Interviews were conducted with the National Land Commission to get the concern on cultural practices and beliefs. The commission recognizes pastoralism as legitimate land use and it has been working closely with the pastoral communities to ensure their peaceful coexistence even during adverse climate conditions when resources for their sustenance are limited. However, the commission itself has come across challenges some of them brought about by members of these communities. Some of its strategies have been strongly opposed by leaders in the region. During an engagement with the one of the commissioners, he indicated that:

Pastoralist communities in and around Nandi County have been embroiled in armed struggles for years, each community with an aim to be the major beneficiary of the resources available across the land. Some of those cases have called for the intervention of this commission. Unfortunately, we still get to hear cases of skirmishes in the region due to a long history of ethnic differences and disagreements.

The results of this study are in agreement with a study conducted by Medard (2010), which pointed out that in the Nandi community, pastoralism is one of the factors that have led to land disputes amongst themselves and with other communities. Since the colonial era, communities living along the Rift Valley region have engaged in altercations over the vital resource of grazing land (Medard, 2010). For instance, the Nandi and the Maasai have constantly been at war especially after independence. There have also been disagreements between the herders and the general population, most of whom are farmers. During the dry spell, the pastoralists move to the least affected areas in search for food and water for their livestock. There have been events where the herders drive their livestock into farmlands with crops and end up fighting with the farmers. These events have been witnessed in other parts of Kenya such as Laikipia County. Most of the areas where the pastoralists originate from are arid and semi-arid parts where even during the best of seasons, food and water for their livestock are still a challenge.

According to study conducted by Anderson (2002), the issue of pastoralism is more likely to lead to more conflict unless an ultimatum is reached by all communities involved. Improper ways of handling the environment such as deforestation resulting to desertification have led to deterioration in the productivity of the land. This has brought about inadequacy of natural resources such as rivers and other water sources, grazing land as well as farming land. This further leads to a scramble for these resources, causing the greater conflicts we get to witness from time to time.

\section{Impacts of Land Disputes in Nandi County}

The study sought to investigate the impacts of land disputes in Nandi County. An open ended questionnaire was used where the counsels and court officers were asked to indicate the effects of land disputes. Members of the National Land Commission were interviewed, and Focus Groups Discussions with village elders were conducted. The results are discussed in this section.

\section{Loss of lives and injury}

In the scramble for land ownership, events of violent encounters between communities often occur and these occurrences always end up with casualties, some die and some are left maimed for the rest of their lives. Due to the sentimental value that is instilled among members of the Nandi community, land dispute rows turn out to be uncontrolled and go to very far extents. Victims of such conflicts are not only left with physical defects but have also had to endure psychological trauma as a result of the abuse they undergo from their rivals and the inhumane actions they witness during such encounters. Interactive sessions were held to help in the assessment. During FGDS, a community elder revealed that:

I have witnessed fathers get into escalated arguments especially with their sons when they start enquiring about getting a share of the family land. Women are not allowed to inherit land in the community so most of these differences occur between fathers and sons or between brothers. Some of these cases have gone so far and resulted to murder. 
The Judiciary, being the arm of government that ensures the implementation of laws, has handled many cases concerning land. The counsels and judicial officers pointed out that death and injuries were so common in the study area. The study population is known to be violent especially when land is mentioned. The respondents pointed out that there have been many deaths and injuries. Some people have been prosecuted because of such actions and many have been jailed.

According to the Penal Code, killing a person is unlawful, an offence of murder results. Section 204 of the Code provides the punishment for murder which is death, for injuries inflicted on a person, if death occurs as a result of the injuries the offence of manslaughter is committed. Section 205 of Code provides the punishment for manslaughter where the accused is liable to imprisonment for life. For injuries sustained with no death the Penal Code provides the punishment depending on the severity of injuries. For simple injuries an offence of assault is established, for severe injuries which can cause impairment the offence of grievous harm is established. Parties involved in land conflicts and where harm has resulted have been arraigned in court as the government tries to curb this menace. One counsel pointed out that there have been cases of assassinations as a result of land ownership disagreements. Most of these cases are within families and arise mostly from the subject of inheritance.

During the interviews with members of the National Land Commission, the study found out that the issue of life loss due to land disputes is common in the study area. The commission is still trying to solve the issue of border disputes following the cases experienced between the Nandi, Kikuyu and Luo communities. Following its establishment under The National Land Commission Act in 2012, the commission has had to deal with land dispute cases that happened prior to its formation. During the interview, a member of the body stated that:

There have been cases of life loss as a result of land dispute in the region and we as the National Land Commission have been on the first row in conducting strategies that could help avoid such incidences in the near future. Some of these cases have happened even before this commission was put together and it has been a great effort trying to follow up on them, but with the aid of other government entities, we have made progress.

Branch (2009) argues that land disputes are dangerous as they cause irreversible damages among the parties. In the African continent where the soil is greatly honored, land conflicts results to deaths and injuries. People fight and are ready to die and leave their descendants with enough pieces of land (Branch, 2009). A land dispute has never been a trivial affair especially when it gets to a point where blood is shed. Families have lost their loved ones over land disputes all over the country. In a report published on $3{ }^{\text {rd }}$ April 2018 by the Daily Nation paper, 111 Murder cases were filed in The High Court in Meru County, 64 in Kiambu County, 39 in Murang'a County, 35 Nanyuki, Laikipia and Embu counties, 17 in Nyeri County and 11 in Chuka, Tharaka-Nithi County (Daily Nation, $3^{\text {rd }}$ April 2018).

\section{Destruction of Property and Resources}

In cases of violence over land ownership and boundary disputes among communities, property is destroyed as a result. Houses are burnt, private property vandalized and in a much greater encounter, government facilities are destroyed too. During FGDs, some of the village elders revealed that cases of outbreak of violence due to land disputes mark the beginning of a miserable phase in their lives which they didn't know how long they would have to persevere. During FGDs held with the village elders of Nandi County, one community elder stated:

I recall during one outbreak of violence over land ownership which involved a father and his eldest son. The disagreement got so bitter that the son decided to burn down his father's house. Fortunately, no life was lost but nothing was saved from the flames.

Some of those who had lost their property resorted to move to court in pursuit of justice. As mentioned earlier, some of the cases were still in court after many years. The internally displaced were still in the camps and some had organized themselves into committees to follow up on their compensation proceedings. Other cases had also come up involving individuals and families too. Both the plaintiffs and defendants have had to pay the cost of expensive lawyers and advocates to help them with their cases. Cases of corruption have resulted from the matter and stable citizens, who were never affected by the outbreaks, pose as fake IDPs in order to acquire the funds paid out to assist the real victims. Cases of cartels colluding to steal money meant for compensation of land dispute victims have also been reported and most of the capital does not get utilized as intended. In a statement published by the Daily Nation paper on $31^{\text {st }}$ August 2018, Directorate of Criminal Investigation (DCI) officials had busted a cartel comprising of 21 persons who are said to be behind fraudulent conspiracies where billions meant for the compensation of IDPs in Nandi were looted. The officials went ahead and reported that false IDPs were paid at the cost of the genuine ones through fraud committed by a former distinguished official of the National Coordination Consultative Committee (NCCC) for IDPs. 
The official is also said to have overseen a conspiracy in which at least 100 acres, meant for the settlement of postelection violence victims, were issued out to phony individuals, among them relatives and allies (Daily Nation, August 31 2018).

In the open-ended questionnaires, the counsels and judicial officers also pointed out that there is destruction of property in the study area because of land disputes. Majority of the respondents indicated destruction to be a major impact. This indicates that whenever there is a conflict, the likelihood of property destruction in Nandi County is always high. One counsel pointed out that there have been cases of corruption where resources issued out by the government for the compensation of land dispute victims have been plundered, leaving the victims to continue enduring the tough conditions as a result. Some of these plots have been carried out by top committee officials who have been entrusted to oversee the compensation programs.

The National Land Commission has had to chip in and deal with the issue of land dispute. Some of the resources it has issued out to help resolve land disputes such as land for the resettlement of squatters and IDPs have not been utilized as intended. As stated earlier, cartels and fake squatters have been forged and plots have been carried out where land has been allocated to the wrong people, leaving the genuine victims of land disputes unattended to. In such cases, hundreds of acres of land have been misappropriated almost every time the commission tries to restore the landless into their homes. In an interview with the one NLC member, it was revealed that:

The commission has endured a lot of deceit from those who carry out schemes to get themselves resources that are not meant for them, some of them being among us in the government. If some of these land dispute standoffs were not so prolonged, then these illegitimate beneficiaries would not have as many loops and opportunities to implement their schemes.

The Constitution of Kenya in Article 40 disallows any person from arbitrarily depriving the other of their property which they have a right to own. Pursuant to that the Penal Code provides for various offences relating to destruction of property specifically malicious injury to property. The property could be a house burnt down in which case the offence of Arson would have been committed whose penalty according to Section 332 of the Penal code one is liable to imprisonment for life. The property destroyed could also be crops in which case the offence of setting fire to crops is established whose penalty according to section 334 of penal code one is liable to imprisonment for 7 years. The destruction could be injuring an animal in which case the offence of injuring an animal has been committed where one is liable to imprisonment for 14 years, or in any case to 3 years depending on injury to the animal. The law does not allow destruction of one's property. Most offences like the ones mentioned though not exclusive are common whenever there are land disputes, people are deprived of the enjoyment and use of their properties which is against the law.

\section{Breaking of Community Ties and Mistrust}

As a result of land dispute, between members of the same family, there develops an atmosphere of mistrust and insecurity between the warring parties. Family members have been known to break their bonds with one another due to quarrels over land possession and inheritance. Social ties are an essential factor in ensuring the well-being of the members of a community as well as the development of the community in general. When disputes occur, what follows is that people grow distant from one another and deeper in consequences where traditions apply, there have been cases where parents and the elderly have cursed their children who engage them in land inheritance disputes.

In a report published by the Daily Nation, there has been an ongoing boundary quarrel between Nandi and Kisumu counties ever since Jaramogi Oginga Odinga was Vice President. As a result, members of the Nandi and Luo communities have engaged each other in occasional strife with cases of bloodshed and leaders from both communities getting into bitter terms with each other (Daily Nation, June 19, 2018). Following this rivalry, it would be almost impossible to bring together these two communities even if need arises. Citizens also find it hard to exploit resources that are available in rival counties. For instance, there are cases where children cannot attend good schools in the rival regions due to fear of being targets of abuse, discrimination and violence. During FGDs with elders of Nandi County, the study came across a Nandi elder who argued that:

The issue of boundary dispute between Kisumu and Nandi County should be revisited as our governor Mr. Sang had suggested earlier. We live in tension with our neighbors in Kisumu to the extent that we cannot even do trade with them. They view us as their rivals and this inhibits social intellectual development between us.

A number of cases have been filed concerning the boundary disputes between the two counties. In a statement published by The Star Newspaper, a court had prolonged directives to prevent the County Government of Kisumu from sharing a piece of land under its mandate with Nandi County. The court had done so after the National Land Commission's absence in the hearing. The hearing had to be postponed for another date (The Star, April 17, 2019). 
This is just one among the many legal issues at bay over the border dispute. The study team came across a number of Counsels. One of Counsels pointed out that both the Nandi and Kisumu County Governments have been at loggerheads with each other over the ownership of towns, fertile lands and industrial areas that stand along the borderline of these two counties. This has caused division among the citizens too and currently, both communities do not see eye to eye. The National Land Commission has weighed in on the matter of boundary dispute between Nandi and Kisumu Counties a couple of times. In cases where fresh definition of the borders has been suggested, the commission has been willing to oversee the formation of these new borderlines but disagreements between these two communities have hindered their efforts of implementation. In a report published on www.cohesion.or.ke, the National Cohesion and Integration Commission has intervened in the affair and has been working closely with the National Land Commission to ensure that a peace treaty between the two counties is implemented. According to the statement, some of the perpetrators in the land dispute cases have been arraigned in court and regulations have been set to hold the offenders accountable (www.cohesion.or.ke, 2019). The study engaged members of the NLC in interview sessions and one member pointed out that:

The commission has been trying to solve any existing conflicts over the Nandi-Kisumu county border to prevent any further drift between these two communities. The NLC has been conducting a reconnaissance and their findings imply that land dispute have been the major cause of inter-community differences in the region.

The Nandi community has been in bad terms not only with the Luo community of Kisumu County but also with other communities such as the Maasai and the Kikuyu. Relations between these civil groups have been sour to the extent where citizens hold prejudice over one another and conflict is always likely to break out. The results of this study are in agreement with Shanguhyia and Koster (2014) who sated that land disputes in Africa create disharmony and mistrust among the conflicting parties. In most cases, a land disputes leads to advanced conflicts in future because of the mistrust that comes up during land disputes.

\section{Development of Poor settlement Schemes and Patterns}

The findings in this study reveal that land disputes lead to poor settlement schemes commonly referred to as slums or informal settlements whereby the conditions of livelihood in such areas are quite poor and uncomfortable. The issue of squatters has been brought up more than once in the past and still is a major challenge today. People who lose their land and fail to get compensated or in cases where compensation is delayed are forced to find some place where they can settle. They come up with quick and easy ways to construct shelter. Most of the housing is of poor quality and gradually, a piece of land occupied by such settlers turns into an informal settlement zone. Due to the poor planning in such places, drainage systems and garbage disposal methods prove to be unsuitable for human health. Residents here suffer from waterborne diseases such as cholera, typhoid, bilharzia and those transmitted by insects such as malaria especially during floods. These areas are also faced with insecurity cases resulting from poverty and drug abuse especially among the youth. Some people move into forest reserves and settle in these prohibited zones. A reconnaissance was conducted in Nandi County and some of the community elders who gave out their views stated that:

After witnessing events of violence as a result if land dispute, most of the residents here find it hard to purchase land or even construct permanent dwellings because often we are being evicted by the government and sometimes driven out of our homes by rival communities during attacks. As a result, we have to avoid investing in construction of homes.

The National Land Commission has been faced with the issues of random and unauthorized settlements being formed. Squatters have often had to leave their homes and move as a result of directives issued out. For instance, in a statement Published by the Daily Nation Newspaper, not less than 100 settlers in Nandi District were evicted for reportedly settling on private land. As a result of the eviction, they were forced to seek accommodation in Mberere and Kipkerere Primary Schools where they have had to endure cold nights (Daily Nation, December 23, 2016.) As a result, these cases, squatters have had to go through hardships because of informal settlements and homelessness. The National Land Commission had the following to say when asked to weigh in on the matter:

We, of course, are aware of some of these cases involving squatters and the authorities. The commission has come across cases of unauthorized settlements and we try as much as possible to bear with the squatters since some of them are there as a result of the heated rows over land ownership. They have nowhere else to go and so it is our role as the oversight body to ensure they belong somewhere instead of just expelling them from their places of refuge. 
Protests have been witnessed as the squatters move to demonstrate against evection directives issued out to them. In a report by Jacob Onyango, 12 people had been arrested in Nandi County following the event of a heated encounter between the police and squatters who had settled in Nyarecho farms, Tinderet sub-county. The squatters vowed to defy any eviction order issued to them under the claims that influential personalities, some of them MPs from Nandi County and MCAs were acquiring land through conspiracy (Onyango, 2019). When asked to weigh in on the matter, one counsel argued that:

The government should move in quickly and sort out the issue of squatters since some of them end up settling in restricted land and end up being engulfed in a series of land dispute cases that cost them much more.

Government entities have put much effort in solving the issue of squatters since decolonization. This comes as a result of change in the tenure systems. Earlier on before the arrival of the British, land was owned collectively and so people never owned land as per individual. After independence, much of the land previously under the British became a source of conflict because decongestion of African could now happen as there was more land left by the colonial government (Elkins, 2005). Some allocated land to themselves while some were left landless as a result and the situation has carried on up to today. Ownership of land is now centralized so one has to purchase land from the government yet it is obvious that squatters do not have the financial capability.

\section{Type of Land Disputes in Nandi County}

The study sought to investigate the type of land disputes in the study area. The counsels and judicial officers were asked to indicate the main type of land disputes they have observed in the line of duty. The results are indicated in Figure 1.

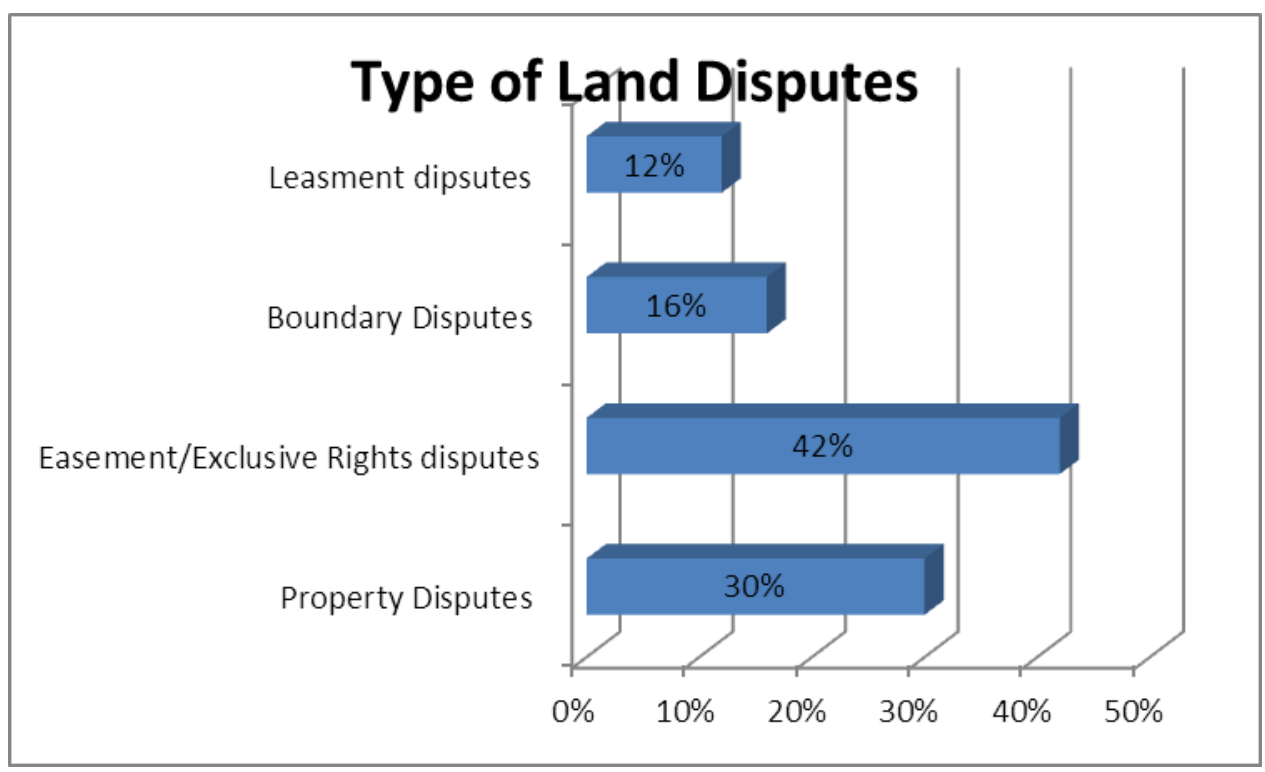

Figure 1 Type of Land Disputes in Nandi County

\section{Source (Field Data, 2019).}

The results in figure 1 indicate that majority of the Counsels and court officials have observed easement/exclusive rights disputes as the major types of land disputes in Nandi County, with a representation of 92(42\%). Property disputes came second with $65(30 \%)$, boundary disputes were third with $35(16 \%)$ while lease disputes were minor with a representation of $26(12 \%)$.

\section{Easement/exclusive Rights Disputes}

Results in Figure 1 indicates majority of the respondents felt that easement/exclusive rights disputes are the major types of land disputes in Nandi County, with a representation of 92(42\%). Often referred to as exclusive easement, this is the privilege given to a particular party to access and utilize a property.

According to Greg (2016), the party is granted exclusive access to the property without actually possessing it and the privileges of an easement holder are based upon the jurisdiction under which the property is (Greg, 2016). However, easement disputes could occur in case one of the parties involved attempts to dishonor the terms of agreement that seal the easement deal. 
During the FGDs with the village elders, it was revealed that there have been cases of easement disputes for instance in Nandi County. For instance, there has been a case whereby two firms namely; Eastern Produce Kenya Ltd. and Chepsire (Savani) Farmers' Co-operative Society Ltd. were involved in an easement dispute. Chepsire Farmers' Cooperative was accused of overlooking the easement privileges it granted to Eastern Produce Kenya on the $19^{\text {th }}$ of December 1979 (Ombwayo, 2017). Eastern Produced Kenya Ltd. had exclusive rights to the property which made them the sole operator on it.

These rights emanate when someone has given another the exclusive rights to use their land for a specified limited purpose. In other words, when a person is granted an easement, he is given the legal right to use the property but the legal title to the land itself remains with the owner of the land. From the findings from interviews with NLC members, this type of disputes is predominant among the residents of Nandi County. Most residents in Nandi County are farmers, and these disputes come about when mostly people enter into easement arrangements on farming land. In the event that the person taking the easement does not use the land for the specified purpose a dispute erupts. It could also be that the easement cannot terminate although the time is up since the plantation did not mature in time as specified (Muigua, 2013). Take an example of a company taking out an easement to put up a tea plantation in Nandi County, if time of easement expires before the company can reap the full benefits of the plantation, the same can bring a dispute since the company may be unwilling to terminate the easement as required. Others will continue trespassing the land after easement has expired. They might still be feeding their animals on that land yet they are not allowed to trespass to it, since they have no rights over it anymore. There are situations where the easement is to expire upon the occurrence of a specified event, the event may take longer than expected due to failure of something like rainfall, resulting into failure of the expected event, the party who gave easement may feel aggrieved and this brings about disputes.

\section{Property Disputes}

Results as indicated in Figure 1 show that $65(30 \%)$ believe that property disputes are rampant. These refer to any legal disagreement involving real estate such as apartments, canals or family homes. Property disputes may involve a variety of characters such as trespassers, family members, landlords and tenants among others (Adams, 2018). Property disputes count for a large segment of cases filed in a year. This could be brought about by inheritance disagreements, political stands, foul trades involved in purchase of land, among others.

This is also prevalent among residents of Nandi County. In one case in Nandi County, Mr. Geoffrey Josiah Kipkemboi Rono was accused by Salawi Investments, who posted as the highest bidder for the piece of land titled Nandi/Cheptarit/014 in an auction that took place on the $22^{\text {nd }}$ of November 1996 at Kapsabet Town (Ombwayo, 2019). The defendant was accused of refusing to vacate the land despite the legal documentation exhibited by the plaintiff, Salawi Investments, and was hereby labeled a trespasser and served with an eviction order.

During the FGDs with the village elders, it was revealed that there is tendency of people invading others properties and settling there with no permission this gives rise to various cases among them: forcible detainer, trespass to property, malicious damage to property. Such disputes have to be solved through the judicial decision making process so as to ensure the owner of the property enjoy their rights on their property. There are cases where a resident will need to feed his animals and just decides to trespass into another's property to feed his animals, the same time these may result in the property of the other being destroyed by the animals, there are also instances where someone is helped a place to farm for a season but goes on to stay there even after the farming season. In fact, the elders argued that such characters even put up a house and stays in the farm, when the owner tells them to move they refuse and a dispute ensues. Others just move in and occupy a vacant land they farm and settle there without permission from the owner committing the offence of forcible detainer. When they are told to move out they refuse such cases have to be taken to court (KLRC, 2019). Interviews with NLC members also pointed out that still there are others who invade public property which the government has to safeguard, not forgetting that community land can also be invaded by people who are not the rightful owners.

\section{Boundary Disputes}

Figure 1 shows that boundary disputes were third with 35(12\%). As the name suggests, there is a disagreement between two or more parties regarding the definition of territory borders. These are mostly experienced in tribal lands whereby the main aim of each party is to extend its borders beyond the rival's definition. They could also involve private land owners in the case of an inconsistent boundary dividing the pieces of land. According to Guo (2018), such disputes may result from ethnic principles and environmental changes and may then hike up into political rivalries (Guo, 2018).During the FGDs with the elders, the study found out that there has been an ongoing boundary dispute between Nandi and Kisumu counties. 
Matoke (2018) documents this and points out that the two have been claiming jurisdiction over several towns positioned along the neighborhood, with boundaries changing from time to time yet no permanent solution has been found to address the issue (Matoke, 2018). The dispute is said to have persisted since the post-colonial era and has led to a number of stand-off situations between these two counties over time.

The NLC members agreed during the interviews that land is a very emotive issue in Nandi County, and it matters a lot that a land owner owns his/her land with no alteration. In the event that two people have doubts as to the boundaries it ends up in court which in conjunction with ministry of land ensures that each person gets their rightful portions. The Kaburwa elders play a big role in this and this has reduced disputes which are boundary based, since their prompt intervention saves the matters being taken to court. The elders understand the boundaries and more so can call on the surveyors who help determine the boundaries. However, this is possible if parties are willing to use their services, others will insist on the matter being taken to court. Further, the study found out from the elders that disputes arise due to residents trespassing to public land. Some even for instance feed their animals in forests or go to forests in search of firewood of go there to burn charcoal. Nandi County is endowed with natural forests and the government is working hard to preserve them, and that is why such activities are not allowed in these forests. However such disputes have significantly gone down.

\section{Lease Disputes}

According to the results in Figure 1, lease disputes were minor with a representation of 26(12\%). These are often disputes between landlords and tenants. However, they can be avoided by careful formulation before implementing a lease. This could be done through negotiations between the landlord and the tenant so as to come up with strategies that could help solve such disputes in case of an event (Fishman, n.d). Lease disputes are most likely brought up by matters such as tenant rights and responsibilities, lease deals, rent, eviction, among others.

Ombwayo (2016) points out that there was an incident in Nandi County whereby one Mr. Harjit Pandhal Singh complained about the prolonged stay of squatters in Kiptegat Farm even after he leased the land. The plaintiff claimed he was asked to give up the lease by the Agricultural Development Co-operation, following an order from the President. The order to commit 1000 acres to squatter settlement is said to have come while Mr. Singh still had leasehold of the land (Ombwayo, 2016). The above lease dispute is clearly as a result of lack of proper planning and setting of terms before implementing the lease.

During FGDs with the village elders, the study found out that such disputes are minimal in Nandi county as shown by the findings of the questionnaires, given the fact that most of the lease disputes are short term leases for farming purposes and mostly easements have overridden the leases, accounting for the lesser no of disputes relating to leases in Nandi county. Members of the NLC added that whenever disputes of this typology arise, they are mostly related to non-payment of lease fee or maybe refusal to let lease property go even after expiry of lease. A lease is more temporary as compared to easement.

\section{Conclusion and Recommendation}

\section{Conclusion}

The study concluded that land disputes have been recurring since the pre-colonial times. The conflicts recur today because the causes have not been tackled, the cultural practices are still upheld. The disputes affect the socio-economic lives of the residents and hinder development, many cannot access their lands, there are many other people who cannot develop their parcels of land because there are cases pending in the courts which bar them from dealing with the lands whatsoever until the cases are determined. They are deprived the use of their lands for long periods time leading to huge losses.

\section{Recommendation}

There is need to address the major causes of land disputes in Nandi so that the conflicts can be prevented from recurring. This can be done if the National governments work with the County government to conduct continuous civic education on the importance of shunning harmful cultural practices that contribute to perpetual land disputes and the importance of dealing with land matters according to the law.

\section{References}

Adams. E. (2018). Legal Match. Property Dispute Lawyers. Retrieved from library/article/property-dispute-lawyers.html

https://www.legalmatch.com/law- 
Anderson, D. (2002). Eroding the Commons: The Politics of Ecology in Baringo, Kenyal890-1963 . Oxford: James Currey, 2002, 41-47.

Andrew, J.S. (2003). Potential application of mediation to land use conflicts in small scale mining. Journal of Cleaner Production, 11, pp. 117-130.

Barnett, J. and W.N. Adger (2007). "Climate change, human security and violent conflict”. Political Geography, 26, pp. $639-655$.

Bogale, A., M. Taeb and M. Endo (2006). Land ownership and conflicts over the use of resources: Implications for household vulnerability in eastern Ethiopia. Ecological Economics, 58, pp. 134-145.

Boone, C., (2012). Land Conflict and Distributive Politics in Kenya, African Studies Review, 55(1):. 75-103

Branch, D. (2009). Defeating Mau Mau, Creating Kenya: Counterinsurgency, Civil War, and Decolonization. New York: Cambridge University Press.

Campbell, D.J., H. Gichohi, A. Mwangi and L. Chege (2000). Land use conflict in Kajaido District, Kenya. Land Use Policy, 17, pp. 337-348.

Civil Procedure Act, Cap 21, Laws of Kenya. Constitution of Kenya, (2010). Government Printer, Nairobi.

County Government of Nandi (2018). Historical and Injustices, Nandi County Progress Report

Elkins, C. (2005). Imperial Reckoning: The Untold Story of Britain's Gulag in Kenya. New York: Henry Holt.

Fishman. B. (n.d). How to Avoid (and Resolve) Landlord and Tenant Disputes. Retrieved from http://www.sior.com/docs/default- source/digitaladvertising/Avoiding\%20and\%20Resolving\%20Landlord\%20an d\%20Tenant\%2Disputes\%20by\%20Bradley\%20S\%20Fishman\%20Summer\% 202007.pdf?sfursn=3b2a0682_0

Greg. F. (2016). Questia. The Doctrine of Lost Modern Grant and Perspective Easement in Newfoundland. Retrieved from https://www.questia.com/library/journal/1P3-4317395681/the-doctrine-of-lost-modern-grant-andprescriptive

Guo. R. (2018). Science Direct: Boundary Dispute. Territorial Disputes and Cross-Border Management. Retrieved from https://www.sciencedirect.com/topics/earth-and-planetary-sciences/boundary-dispute

Hughes, H. (2006). Moving the Maasai: A Colonial Misadventure. New York: Palgrave Macmillan.

Jackson,T.(2009). The Law of Kenya ( $3^{\text {rd }}$ edition), Kenya Literature Bureau, Nairobi.

Judiciary. (2019). Environment and Land Court. Retrieved from https://www.judiciary.go.ke/courts/environment-and-landcourt/

Kagwanja, P. "Facing Mount Kenya or Facing Mecca? The Mungiki, Ethnic Violence and the Politics of the Moi Succession in Kenya, 1987- 2002." African Affairs 102, no. 406 (January 2003): 25-49.

Kagwanji, P. (2009). Ethnicity, land and conflict in Africa: The cases of Kenya, Uganda, Tanzania and Rwanda. Nairobi, Africa Policy Institute Working Paper Series.

KLRC. (2019). Constitution of Kenya. Retrieved from http://www.klrc.go.ke/index.php/constitution-of-kenya/117-chapterfive-land-and-environment/part-1-land/234-67-national-land-commission

Maina, M. (2015). Land Disputes Resolution in Kenya: A Comparison Of The Environment And Land Court And The Land Disputes Tribunal. Masters' Thesis, University Of Nairobi.

Matoke. T. (2018). Daily Nation. Kisumu, Nandi Border Takes New Twist. Retrieved from https://www.nation.co.ke/news/Kisumu--Nandi-border-dispute-takes-new-twist/1056-4619430-csbwng/index.html

Medard, C. (2010). "Indigenous Land Claims in Kenya: A Case Study of Chebuyuk, Mount Elgon District," In The Struggle over Land in Africa: Conflicts, Politics and Change, edited by Ward Anseeuw and Chris Alden. Cape Town: HSRC Press, 2010.

Muigua, D. K. (2015). Empowering the Kenyan people through alternative dispute resolution mechanisms. Nairobi: UON Press

Ombwayo. A. (2016). Kenya Law. E \& L Case 20 of 2013. Retrieved from

http://kenyalaw.org/caselaw/cases/view/123362

Ombwayo. A. (2017). Kenya Law. Environment and Land Case 87 of 2016. Retrieved from http://kenyalaw.org/caselaw/cases/view/131214

Ombwayo. A. (2019). Kenya Law. Environment and Land Case 102 of 2012 [Formerly Eldoret HCCC156 of 2002 ]. Retrieved from http://kenyalaw.org/caselaw/cases/view/167260/

Rugege, D., U. Bob, V. Moodley, S. Mtshali, O. Mutanga and A. Mthembu (2007). A literature review for the Baseline Survey on Communal Land Rights Act in KwaZulu Natal. Submitted to the Department of Land Affairs, Pretoria.

Scurrah,N. and Hirsch, P. (2015). Dispute Resolution and access to justice. Mekong Region.

Shanguhyia M., Koster M.M. (2014). Land and Conflict in Kenya's Rift Valley: Historical and Contemporary Perspectives. In: Falola T., Mbah E.M. (eds) Contemporary Africa. African Histories and Modernities. Palgrave Macmillan, New York

Viljoen, M.F. (2006). Bridging the economic divide in South African agriculture by improving access to natural resources. Agrekon, 45 (1), pp. 1-16. 